\title{
PENGARUH CR, DER, DAN BOPO TERHADAP ROA PADA KOPERASI DI KABUPATEN BONE BOLANGO
}

\author{
Yasir M. Pidu
}

Dosen Fakultas Ekonomi dan Bisnis Universitas Terbuka

\begin{abstract}
Abstrak:Return On Asset (ROA) merupakan salah satu rasio profitabilitas yang digunakan untuk mengukur efektivitas perusahaan dalam menghasilkan keuntungan dengan memanfaatkan total yang dimilikinya.Penelitian ini bertujuan mengetahui pengaruh Current Ratio, Debt Equity Ratio dan BOPO terhadap Return On Asset baik secara simultan, maupun parsial pada Koperasi di Kabupaten Bone Bolango.Penelitian ini menggunakan data keuangan Koperasi di Kabupaten Bone Bolango yang diambil secara purposive sampling, sehingga sampel diperoleh 30 data keuangan koperasi selama 5 tahun. Data tersebut dianalisis dengan menggunakan analisis regresi. Hasil Penelitian uji simultan (uji f) menunjukkan, bahwa variabel Current ratio, Debt Equity Ratio dan BOPO secara bersama - sama berpengaruh terhadap Return On Asset, sedangkan hasil uji parsial (uji t) menunjukkan bahwa variabel debt equity ratio dan BOPO berpengaruh terhadap Return On Asset.
\end{abstract}

Kata Kunci :Profitabilitas, Return On Asset, Koperasi.

\begin{abstract}
Return on Assets(ROA) is aprofitability ratiothat isusedtomeasure theeffectiveness ofthe companyin generatingprofitsby exploitingitstotal.The research aimed at investigating : the effect of Current Ratio, Debt Equity Ratio, And Bopo Toward Return On Assets In either simultaneousandpartial in District Bone Bolango. The sample was selected using purposive sampling method consisting of 30 financial statement cooperative five period. The data were analyzed using multiple regression analysis.The research result of simultaneous test ( $f$-test) indicates that the variable current ratio, Debt Equity Ratio and ROA the same effect on the Return On Asset, whereas to partial test results ( $t$-test) indicates that the variable, debt equity ratio and BOPO affect on Return On Asset.
\end{abstract}

Key Words :Profitability, Return On Asset, Cooperative.

\section{PENDAHULUAN}

Semakin kompetitifnya dunia usaha, koperasi dituntut untuk secara kontinyu menyempurnakan kinerjanya agar dapat beroperasi dengan baik dan efisien sehingga mampu meningkatkan laba pada koperasi pertahunnya. Karena Koperasi adalah suatu organisasi ekonomi rakyat, yang mempunyai dua sifat: social dan ekonomis. Pada awal abad-19 koperasi berkembang sebagai bentuk bisnis, (Birchall, 1997, at.el., Lopez, 2009). Koperasi dikembangkan sebagai asosiasi terdiri dari anggota organisasi; berbeda dari organisasi lain dalam hal bentuk organisasi dan tujuan ekonomi mereka. Ada beberapa karakteristik yang membedakan koperasi dengan bentuk lain dari perusahaan adalahhubungan anggota koperasi sebagai pemilik, controller, dan peserta di koperasi, (Birchall, 2005 at.el., Lopez, 2009).Koperasi bersifat social artinya koperasi itu merupakan kumpulan orang yang berusaha untuk saling menolong dan bukan hanya kumpulan modal yang melului berorientasi pada laba saja. Koperasi di Indonesia dilandasi pada Undang - undang dasar 1945 pasal 33 dan diatur menurut UU No. 25 Tahun 1992 tentang Perkoperasian Bab I Pasal 1 Koperasi adalah " Badan usaha yang beranggotakan orang - orang atau badan hukum koperasi dengan melandaskan kegiatannya berdasarkan prinsip koperasi sebagi 
gerakan ekonomi rakyat yang berdasarkan atas asas kekeluargaan". Pada pasal 3 UU No. 25 tahun 1992 dimana yang berbunyi bahwa Koperasi bertujuan memajukan kesejahteraan anggota pada khususnya dan masyarakat pada umumnya serta ikut membangun tatanan perekonomian dalam rangka mewujudkan masyarakat yang maju, adil dan makmur berdasarkan Pancasila dan UUD 1945. Ada tidaknya kemajuan dan perkembangandalam bidang keuangan koperasi diperlukan suatu alat yang mampu memberikan informasi keuangankepada pihak-pihak yang ber kepentingan terhadapperkembangan koperasi. Laporan keuanganmerupakan sumber informasi yang dapatdigunakan untuk tujuan tersebut. Dalam laporan keuangan koperasi di Kabupaten Bone Bolango adanya penurunan dan peningkatan laba tiap tahun, sehingga dapat berpengaruh terhadap pengembalian kepada anggota koperasi (SHU).Return OnAsset(ROA) merupakan salah satu rasio profitabilitas yang digunakan untuk mengukur efektivitas perusahaan dalam menghasilkan keuntungan dengan memanfaatkan total yang dimilikinya. Atau membandingkan antara hasil usaha yang diperoleh dengan asset koperassi pada tahun yang bersangkutan. Semakin besar ROA menunjukkan kinerja perusahaan semakin baik, karena return semakin besar.

Rasio keuangan adalah penulisan ulang data akuntansi ke dalam bentuk perbandingan dalam rangka mengidentifikasi kekuatan dan kelemahan keuangan perusahaan (Keown dkk, 2013). Rasio keuangan menunjukkan hubungan keuangan dengan membagi satu item keuangan dengan item keuangan lain dan merupakan alat penting bagi manajemen, memungkinkan perbandingan ruang untuk menempatkan perusahaan dalam lingkungannya (Livnat \& Zarowini, 1990).

Return on Assets (ROA) menunjukkan kemampuan perusahaan menghasilkan laba dari aktiva yang dipergunakan, dimana rasio ini dihitung dengan cara membagi laba setelah pajak dengan aktiva rata - rata, (Sugiyarso, 2011). Pada Koperasi bahwa Return on Asset merupakan perbandingan antara Sisa Hasil Usaha (SHU) dengan asset yang dimiliki oleh koperasi pada tahun yang bersangkutan.

$$
R O A=\frac{S H U}{\text { Total Asset }} X 100 \%
$$

Current ratio merupakan salah satu ratio yang mengukur tingkat likuditas dari perusahaan, dimana ratio likuditas adalah kemampuan perusahaan memenuhi kewajiban jangka pendeknya secara tepat waktu. Current ratio merupakan perbandingan antara aktiva lancar dengan utang lancar.

Current Ratio $=\frac{\text { Aktiva Lancar }}{\text { Hutang Lancar }} \times 100 \%$

Kondisi perusahaan yang memiliki Current ratio yang baik adalah dianggap sebagai perusahaan yang baik dan bagus, namun jika current ratio terlalu tinggi juga dianggap tidak baik seperti dikatakan oleh Samuel C. Weaver dan J. Fred Weston nahwa ini megindikasikan adanya masalah (Fahmi, 2012).

Debt Equity Ratio merupakan kebijakan pendanaan yang tercermin,dalam debt equity ratio (DER) sangat mempengaruhi pencapaian laba yang diperoleh perusahaan.Semakin tinggi 
DER menunjukkan semakin besar kepercayaan dari pihak luar, hal ini sangat memungkinkan meningkatkan kinerja perusahaan/koperasi, karena dengan modal yang besar maka kesempatan untuk meraih tingkat keuntungan juga besar. Rasio ini merupakan perbandingan total hutang yang dimiliki koperasi dengan modal sendiri (Ekuitas).

$D E R=\frac{\text { Total Kewajiban }}{\text { Total Ekuitas }} \times 100 \%$

Rasio $B O P O$ disebut rasio efisiensi ini digunakan untuk mengukur kemampuan manajemen dalam mengendalikan biaya operasional terhadap pendapatan operasional.Semakin kecil rasio ini berarti semakin efisien biaya operasional yang dikeluarkan koperasi yang bersangkutan sehingga kemungkinan suatu koperasi dalam kondisi bermasalah semakin kecil,semakin besar BOPO semakin kecil/menurun kinerja keuangan, begitu juga sebaliknya.

$$
\text { BOPO }=\frac{\text { Total Beban Operasional }}{\text { Total Pendapatan Oprasional }} \times 100 \%
$$

Dalam penelitian ini memfokuskan permasalahan pada variabel Current ratio, Debt Equity Ratiodan BOPO dapat memengaruhi Return On asset pada Koperasi di Kabupaten Bone Bolango.

Penelitian dari Jiasti (2010), hasil penelitiannya bahwa Current Ratio (CR) berpengaruh positif dan signifikan terhadap laba usaha pada koperasi Kopersemar. Sarjana, dkk. (2013). hasil penelitian menunjukkan bahwa current ratio, debt to equity ratio, receivable turnover dan cash turnover menunjukkan pengaruh yang tidak signifikan pada Koperasi Serba Usaha di Kabupaten Buleleng. Penelitian oleh Ikhsan \& Solikha (2011), hasil penelitian menunjukkan bahwa likuiditas tidak berpengaruh terhadap rentabilitas koperasi, solvabilitas berpengaruh negatif terhadap rentabilitas koperasi, efisiensi pengendalian biaya berpengaruh negatif terhadap rentabilitas ekonomi. Rahmawati (2009), Debt Equity Ratio berpengaruh terhadap ROA. Penelitian dilakukan oleh Gwey \& Karanja. (2014),bahwa Debt Equity Ratio tidak berpengaruh terhadap Return On Asset dan Pertumbuhan Pendapatan pada koperasi di Kenya. Penelitian ini bertujuan untuk mengetahui pengaruh variabel Current ratio, Debt Equity Ratio dan BOPO terhadap Return On Asset pada Koperasi di Kabupaten Bone Bolango.

Maksud dari penelitian ini adalah untuk mengetahui current ratio, debt equity ratio dan BOPO berpengaruh terhadap return on asset pada koperasi di Kabupaten Bone Bolango.

Penelitian ini dapat dipergunakan bahan perbandingan antara teori dengan praktek, digunakan sebagai bahan masukan bagi pimpinan untuk mengetahui apakah kenaikan modal Koperasi menguntungkan atau tidak dan dengan menghitung rasio-rasio tertentu akan memperoleh suatu informasi tentang kekuatan dan kelemahan yang dihadapi koperasi,sehingga dapat membuat keputusan - keputusan yang penting bagi kepentingan koperasi untuk masa yang akan datang.Bagi manajemen untuk pengendalian internal dan pengambilan keputusan pendanaan serta keputusan investasi dalam rangka pengembangan usahanya. Bagi para kreditur dan 
para investor, anggota dapat digunakan untuk lebih memahami sifat dasar dan karasteristik operasional dari suatu koperasi sebagai dasar pengambilan keputusan investasi

\section{METODE PENELITIAN}

Penelitian ini adalah penelitian eksplanatori yaitu penelitian yang bertujuan untuk menganalisis pengaruh antara variabel, dengan melihat tingkat signifikansinya.Penelitian ini dilakukan di Dinas Perindustrian Perdagangan dan Koperasi Kabupaten Bone Bolango. Dalam penelitian ini Populasi berjumlah 118. Teknik yang digunakan untuk pengambilan sampel dilakukan melalui metode purposive sampling dengan tujuan untuk mendapatkan sampel yang sesuai dengan tujuan penelitian.Metode purposive sampling merupakan metode pengambilan sampel yang didasarkan pada beberapa kriteria atau pertimbangan tertentu (Sugiyono, 2008). Sampel yang diambil dalam penelitian adalah 30 Koperasi yang berupa laporan keuangan neraca, laporan keuangan laba rugi, dan laporan perhitungan hasil usaha koperasi yang ada di Kabupaten Bone Bolango dari tahun 2010 2014 atau selama 5 tahun. Menurut Roscoe, 1975 dimana ukuran sampel lebih dari 30 dan kurang dari 500 adalah tepat untuk kebanyakan penelitiandalam (Sekaran, 2011).

Dalam penelitian ini peneliti menggunakan dua varibel yaitu Variabel Dependent (terikat) dan Variabel Independent (Bebas). Variabel Dependent dalam penelitian ini adalah Return On asset (Y), sedangkan variabel Independent sebagai berikut :

X1 : Current Ratio

X2 : Debt Equity Ratio

\section{X3 : BOPO}

Dalam penelitian ini metode yang digunakan adalah Model regresi linier berganda (multiple linier regression method), yang dirumuskan sebagai berikut (Ghozali \& Fuad, 2005): $\boldsymbol{Y}=\boldsymbol{a}+\boldsymbol{b}_{1} \boldsymbol{X}_{1}+\boldsymbol{b}_{2} \boldsymbol{X}_{2}+\boldsymbol{b}_{3} \boldsymbol{X}_{3}+\boldsymbol{\alpha}$

Variabel dependent (terikat )Return On Asset besar kecilnya ditentukan oleh variabel independent (bebas) ; Current Ratio, Debt Equity Ratio, dan BOPO. Alat yang digunakan untuk menganalisis ini dengan menggunakan Model Regresi, untuk mempermudah analisis regresi pengolahan data penelitian ini menggunakan program SPSS 20.0.

\section{HASIL PENELITIAN}

\section{Uji Normalitas}

Berdasarkan uji Normalitas menggunakan grafik hasil pada gambar 1 uji normalitas menggunakan analisis grafik bahwa bahwa ada kecenderungan membentuk kurva bel, dengan demikian dapat dikatakan bahwa data yang digunakan terdistribusi dengan normal sedangkan hasil pada gambar 2 menunjukkan data terdistribusi secara normal karena distribusi data residualnya menyebar di sekitar garis diagonalnya dan mengikuti arah garis diagonal tersebut, sehingga memenuhi asumsi normalitas. Untuk uji statistik menggunakan Uji KolmogorovSmirnov pada tabel 1 didapat Hasil pengujian KolmogorvSmirnov test menunjukkan bahwa data terdistribusi normal. Hal ini ditunjukkan dengan nilai Kolmogorov-Smirnov adalah 0,883 dengan signifikansi pada 0,417 yang lebih besar dari 0,05 hal ini berarti data residual terdistribusi secara normal. Hasil diatas juga didukung hasil grafik 
histogram maupun grafik Normal Probability Plotnya.

\section{Pengujian Hipotesa}

Hail uji F/ANOVA pada tabel 2 menunjukkan nilai $\mathrm{F}$ hitung sebesar 10.380, Nilai ini lebih besar dari nilai $\mathrm{F}$ begitu juga dengan sign yang lebih kecil dari alpha 5\%. Didapat bahwa secara bersama - sama (simultan) varibel bebas memengaruhi Return On Asset.

Hasil uji t pada tabel 3 menunjukkan bahwa Koefisien current ratio dengan nilai -0,842 dan nilai kooefisien 0,401 (0,401>0,05 ) menunjukkan bahwa current ratio tidak berpengaruh signifikan terhadap Return On Assetmaka Ho diterima.Nilai Koefisien Debt Equity Ratio sebesar -3,830dengan nilai sebesar nilai signifikansi $0,000(0,000<0,05)$ maka H0ditolakartinya Debt Equity Ratio berpengaruh terhadap Return on Asset. Koofisien nilai BOPO sebesar $-3,082$ dengan nilai signifikansinya $0,002(0,002<0,05)$ maka H0 ditolakhal ini menunjukkan bahwa ratio BOPO berpengaruh signifikan terhadap Return On Asset. Berdasarkan hasil pada tabel 3 menunjukkan bahwa persamaan regresi didapat :

$\mathrm{Y}=1,878-0,082 \mathrm{CR}-0,224 \mathrm{DER}-0,212 \mathrm{BOPO}$

Nilaikonstanta sebesar 1,878 menunjukkan bahwa tanpa adanya pengaruh variabel Current Ratio (CR), Debt Equity Ratio (DER), dan BOPO maka nilai Return On Asset pada koperasi hanya sebesar 1,88\%. Nilai Slope -0,082CR menunjukkan bahwa setiap kenaikan Return On Asset sebesar 1\% maka hal tersebut akan menurunkan Current Ratio sebesar 0,082\% dan sebaliknya. Nilai Slope -0,224DER menunjukkan bahwa setiap kenaikan Return On asset sebesar 1\% maka hal tersebut akan menurunkan nilai Debt Equity Ratio sebesar 0,224\% dan sebaliknya.Nilai Slope sebesar -0,212BOPO menunjukkan bahwa setiap kenaikan Return On asset sebesar 1\% maka hal tersebut akan menurunkan nilai BOPO sebesar $0,212 \%$, dan sebaliknya.

\section{PEMBAHASAN}

Berdasarkan hasil analisis diperoleh bahwa Ratio keuangan antara lain Current Ratio, Debt Equity Ratio dan BOPO dapat memengaruhi Return On Asset artinya bahwa ratio tersebut dapat digunakan untuk menganalisis Return On asset.

Berdasarkan hasil analisis uji t (uji parsial), hasil penelitian menunjukkan Current ratio tidak berpengaruh terhadap Return On Ratio pada koperasi di Kabupaten Bone Bolango. Penelitian ini mendukung penelitian dari Ikhsan\& Solikha (2011), likuiditas tidak berpengaruh terhadap rentabilitas koperasi pada koperasi pegawai republik Indonesia (kpri) di Jawa Tengah. Sarjanadkk., (2013) menunjukkan hasil bahwa current ratiomenunjukkan pengaruh yang tidak signifikan pada Koperasi Serba Usaha di Kabupaten Buleleng. Penelitian ini menolak dari penelitian Jiasti (2010), hasil penelitiannya bahwa Current Ratio (CR) berpengaruh positif dan signifikan terhadap laba usaha pada koperasi Kopersemar.

Hasil penelitan uji t (uji parsial) pada Debt Equity ratio menunjukkan bahwa Debt Equity ratio berpengaruh terhadap Return On Asset, hasil penelitian ini sejalan dengan penelitian yang 
dilakukan oleh Rahmawati (2009), Debt Equity

Ratio berpengaruh terhadap ROA. Penelitian ini menolak yang dilakukan olehSarjana dkk. (2013).debt to equity ratio,pengaruh yang tidak signifikan pada Koperasi Serba Usaha di Kabupaten Buleleng.Ikhsan \& Solikha (2011), dimana hasil penelitian menunjukkan bahwa solvabilitas berpengaruh negatif terhadap rentabilitas koperasi. Gwey \& Karanja (2014), bahwa Debt Equity Ratio tidak berpengaruh terhadap Return On Asset.

Hasil penelitian uji $\mathrm{t}$ (uji parsial) pada BOPO dimana BOPO berpengaruh terhadap Return On Asset. Penelitian ini mendukung penelitian dari Ikhsan \& Solikha (2011), hasil penelitian menunjukkan bahwa efisiensi pengendalian biaya berpengaruh negatif terhadap rentabilitas ekonomi. Mawardi (2005), BOPOpengaruh negatif terhadap ROA. Mahardian (2008), Efisiensi Operasi (BOPO) berpengaruh negatif signifikan terhadap Return on Asset (ROA), Hasil penelitian ini menolak penelitian dari Sabir dkk., (2012) menyatakan BOPO tidak berpengaruh terhadap ROA pada bank konvensional.

Pada Current ratio, Debt Equity Ratio dan BOPO apabila terjadi kenaikan maka hal ini dapat menurunkan nilai Return Asset sehingga pengembalian terhadap anggota koperasi akan semakin sedikit. Sedangkan pada Net Profit Margin dan Net Interest Marrgin terjadi kenaikan maka return On Asset dapat mengalami kenaikan. Semakin baik rasio profitabilitas maka semakin baik menggambarkan kemampuan tingginya perolehan keuntungan perusahaan, (Fahmi, 2012).

\section{KESIMPULAN DAN SARAN}

Berdasarkan hasil analisis uji simultan maka diketahui bahwa current ratio, debt equity ratio dan BOPO secara bersama - sama dapat memengaruhi Return On Asset pada koperasi di Kabupaten Bone Bolango. Secara parsial bahwa rasio debt equity ratiodan $\mathrm{BOPO}$ yang dapat memengaruhi return on assetsedangkan untuk variabel current ratio secara parsial tidak berpengaruh terhadap return on asset. Hasil penelitian juga menunjukkan return on asset naik $1 \%$ maka nilai current ratio, debt equity ratio dan BOPO akan turun.

Untuk menganalisis return on asset pada koperasi di Kabupaten Bone Bolango disarankan mengabaikan current ratio. Koperasi di Kabupaten Bone Bolango dalam rangka meningkatkan nilai return on asset disarankan dapat menurunkan nilai current ratio, debt equity ratio, BOPO dan menaikkan nilai net profit margin, net interest margin. Untuk penelitian selanjutnya diharapkan menggunakan ratio keuangan yang belum diteliti pada penelitian ini.

Implikasi dari penelitian ini bahwa manajer koperasi di Kabupaten Bone Bolango dalam menaikkan ratio laba dapat menurunkan ratio debt equity ratio dan tingkat ratio dari BOPO artinya bahwa manajer lebih mengurangi hutang dan menurunkan biaya operasional atau lebih efesiens.

\section{DAFTAR PUSTAKA}

Fahmi.Irham.(2012).Analisis Kinerja Keuangan, penerbit CV Alfabeta, Bandung

Ghozali,Imam \& Fuad. (2005).Structural Equation Modeling, Teori, Konsep\& Aplikasi dengan Program LISREL 8.54, 
Semarang: Badan Penerbit Universitas Diponegoro, 2005

Gwey. Moses Ochieng \& Karanj. John. (2014).Effect of Financial Leverage on Financial Performance of Deposit Taking Savings and Credit Cooperative in Kenya, Vol. 4, No.2, April 2014, pp. 180-188, E-ISSN: 22258329, P-ISSN: 2308-0337

Ikhsan.Sukardi \& Solikhah. Badingatus. (2011). Analisis Rentabilitas Pada Koperasi Pegawai Republik Indonesia (Kpri) Di Jawa Tengah. Jurnal Dinamika Akuntansi, Vol. 3, No. 2, September 2011, pp. 120-128, ISSN 2085-4277.

Jiasti. Fiska \& Devi. (2010). Analisis Pengaruh Current Ratio, Quick Ratio, Receivable Turn Over, Dan Cash Turn Over Terhadap Laba Usaha (Koperasi Kopersemar Periode Tahun 20072009). Fakultas Ekonomi Universitas Diponegoro. Semarang.

Keown, Arthur J dkk. (2011). Manajemen Keuangan: Prinsip dan Penerapan. Edisi Kesepuluh.

Jilid 1. Jakarta. Terjemahan oleh Marcus Prihminto Widodo. 2008. PT Indeks.

Livnat. Joshua \& Zarowin. Paul. (1990).The Incremental Information Content of Cash-Flow Components, Journal of Accounting and Economics 13 (1990) 25-46.

Lopez-Espinosa. German. John Maddocks. Fernando Polo Garrido.(2009).Eqiuty Liabilities Distinction: The Case for Co-operatives, Journal of International Financial Management and Accounting 20:3 2009.

Mahardian. Pandu. (2008).Analisis Pengaruh Rasio Car, Bopo, Npl, Nim Dan Ldr Terhadap Kinerja Keuangan Perbankan (Studi Kasus Perusahaan Perbankan Yang Tercatat

Di Bej Periode Juni 2002 - Juni 2007). Tesis ;Program Studi Magister
Manajemen Program Pascasarjana Universitas Diponegoro. Semarang

Mawardi. W. (2005).Analisa Faktor Faktor yang Mempengaruhi Kinerja Keuangan Bank Umum di Indonesia (Studi Kasus pada Bank Umum dengan Total Asset Kurang dari 1 Triliun), Jurnal Bisnis Strategi, Vol.14, No.1, Juli, pp.83-94.

Sabir dkk. (2012).Pengaruh Rasio Kesehatan Bank terhadap Kinerja Keuangan Bank Umum Syariah dan Bank Konvensional Di Indonesia, Jurnal Analisis, Juni 2012, ISSN 2303-100,Vol.1 No.1 : 79 -86 .

Sarjana dkk. (2013).Analisis Kinerja Keuangan pada Koperasi Serba Usaha di Kabupaten Buleleng. Jurnal Manajemen Agribisnis. ISSN: 23550759. Vol. 1, No. 2, Oktober 2013

Sekaran. Uma. (2011).Metodologi Penelitian untuk Bisnis. Salemba Empat. Jakarta.

Sugiyarso. Gervasius. (2011). Akuntansi Koperasi ( Sistem, Metode, dan Analisis Laporan Keuangan ). Yogyakarta.CAPS

Sugiyono. (2008).Metode Penelitian Kunatitatif Kualitatif dan $R \& D$. Bandung. Alfabeta. http://www.depkop.go.id/. 